\title{
Assessing the Systemic Effects of Two Different Doses of Intra-Articular Triamcinolone Acetonide in Healthy Dogs
}

\author{
Lauri-Jo Gamble ${ }^{1}$ Jordyn M. Boesch ${ }^{1}$ Joseph J. Wakshlag ${ }^{1}$ Christopher W. Frye ${ }^{1(0)}$ \\ ${ }^{1}$ Department of Clinical Sciences, College of Veterinary Medicine, \\ Address for correspondence Christopher W. Frye, DVM, 930 Campus \\ Cornell University, Ithaca, New York, United States \\ Rd, Ithaca, NY 14853, United States (e-mail: cwf37@cornell.edu).
}

VCOT Open 2020;3:e96-e102.

\begin{abstract}
Keywords

- corticosteroid

- joint

- canine

- safety

Objective Osteoarthritis is a common cause of pain and dysfunction in dogs. Intraarticular (IA) corticosteroids have been used to treat human and animal osteoarthritis; however, their systemic effects have not been well documented in dogs. Therefore, our objective is to determine if a single IA triamcinolone acetonide (TA) injection, at two different doses, suppresses the hypothalamic-pituitary-adrenal axis, induces alkaline phosphatase (ALP), or causes other clinicopathological abnormalities in dogs.

Study Design Six healthy female intact adult mongrel dogs from a research colony. For phase one, dogs were randomly assigned to injection of $0.25 \mathrm{mg} / \mathrm{kg}$ TA into the right $(n=3)$ or left $(n=3)$ stifle. Haematology, liver-related biochemistry and adrenocorticotropic hormone stimulation tests were conducted the day prior to injection and repeated on days 1, 3 and 7, and then weekly after injection until values normalized. Following a 2-week washout period, $0.5 \mathrm{mg} / \mathrm{kg}$ TA was injected into the contralateral stifle (phase two), and laboratory testing mimicked phase one.

Results Mild, transient adrenocortical suppression occurred in both phases, beginning on day 1 and resolving by days 3 and 7 in phases one and two respectively. However, post-adrenocorticotropic hormone stimulation cortisol levels were never outside the normal range for either phase. Alkaline phosphatase activity increased on day 3 in phase two but remained within normal limits. Mild stress leukograms occurred on day 1 in both phases. No clinical abnormalities were noted throughout the study. Conclusion Systemic adverse effects following IA TA stifle injections at $0.25 \mathrm{mg} / \mathrm{kg}$ and $0.5 \mathrm{mg} / \mathrm{kg}$ are unlikely.
\end{abstract}

\section{Introduction}

Osteoarthritis (OA) is one of the most common causes of pain, impaired mobility, functional disability and poor quality of life. A wide variety of pharmacologic and non-pharmacologic therapies are used to relieve OA pain in human and veterinary patients. ${ }^{1-3}$ However, $~ 12 \%$ of dogs with OA still fail to achieve significant pain relief. ${ }^{4}$

received

May 2, 2020

accepted after revision

July 23,2020
DOI https://doi.org/

10.1055/s-0040-1716375. ISSN 2625-2325.
Intra-articular (IA) triamcinolone acetonide (TA) injections are commonly performed in humans and horses as an anti-inflammatory and analgesic agent for OA..$^{5-16}$ Although horses and people may clinically benefit from IA glucocorticoids, including TA, there is also evidence of local chondrotoxicity, particularly with repeat dosing., ${ }^{50-16}$ The putative systemic side effects of corticosteroid usage most commonly cited (including topical and intramuscular TA)

(C) 2020 Georg Thieme Verlag KG License terms Stuttgart · New York

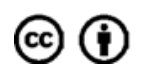


include adrenocortical suppression, insulin resistance and iatrogenic hyperadrenocorticism (HAC). ${ }^{17-19}$

In people, $40 \mathrm{mg}$ of TA ( $0.5 \mathrm{mg} / \mathrm{kg}$ for average adult) represents a common IA knee dose. ${ }^{8,10}$ Anecdotally, similar clinical dosing $(0.25-0.5 \mathrm{mg} / \mathrm{kg} \mathrm{IA})$ is applied to dogs. In contrast to horses and people, repeat IA dosing of $0.25 \mathrm{mg} / \mathrm{kg}$ of triamcinolone hexacetonide $(\mathrm{TH})$ showed cartilage sparing for canine OA. ${ }^{20-22}$ However, in healthy joints, a recent study regarding the local effects of IATA and extended release TA(TA-ER) in dog stifles did demonstrate mild adverse cartilage effects including a reduction in Safranin $O$ staining (indicative of proteoglycan loss within the cartilage matrix) and rarely mild focal structural damage. ${ }^{23}$ During follow-up, Safranin 0 loss showed capacity for recovery, and cartilage effects were considered mild and transient. Although anecdotal clinical response appears promising with minimally adverse to potentially cartilage sparing effects locally, the systemic influence of IA triamcinolone in dogs, remains unexplored.

The primary aim of this study was to determine if TA (a related preparation to $\mathrm{TH}$ ) suppresses the hypothalamic-pituitary-adrenal axis (HPA) after single IA injection by monitoring changes in adrenocorticotropic hormone (ACTH) stimulation tests. Secondary aims were to determine if IA TA (1) increases serum alkaline phosphatase (ALP) activity and (2) causes other clinicopathological abnormalities consistent with iatrogenic HAC on standard haematology and liver related biochemistry testing. We hypothesized that IA administration of either 0.25 or $0.5 \mathrm{mg} / \mathrm{kg}$ TA into healthy adult dog stifles will cause (1) adrenocortical suppression, (2) serum ALP elevation and (3) other clinicopathologic abnormalities consistent with iatrogenic HAC that resolve within 2 weeks.
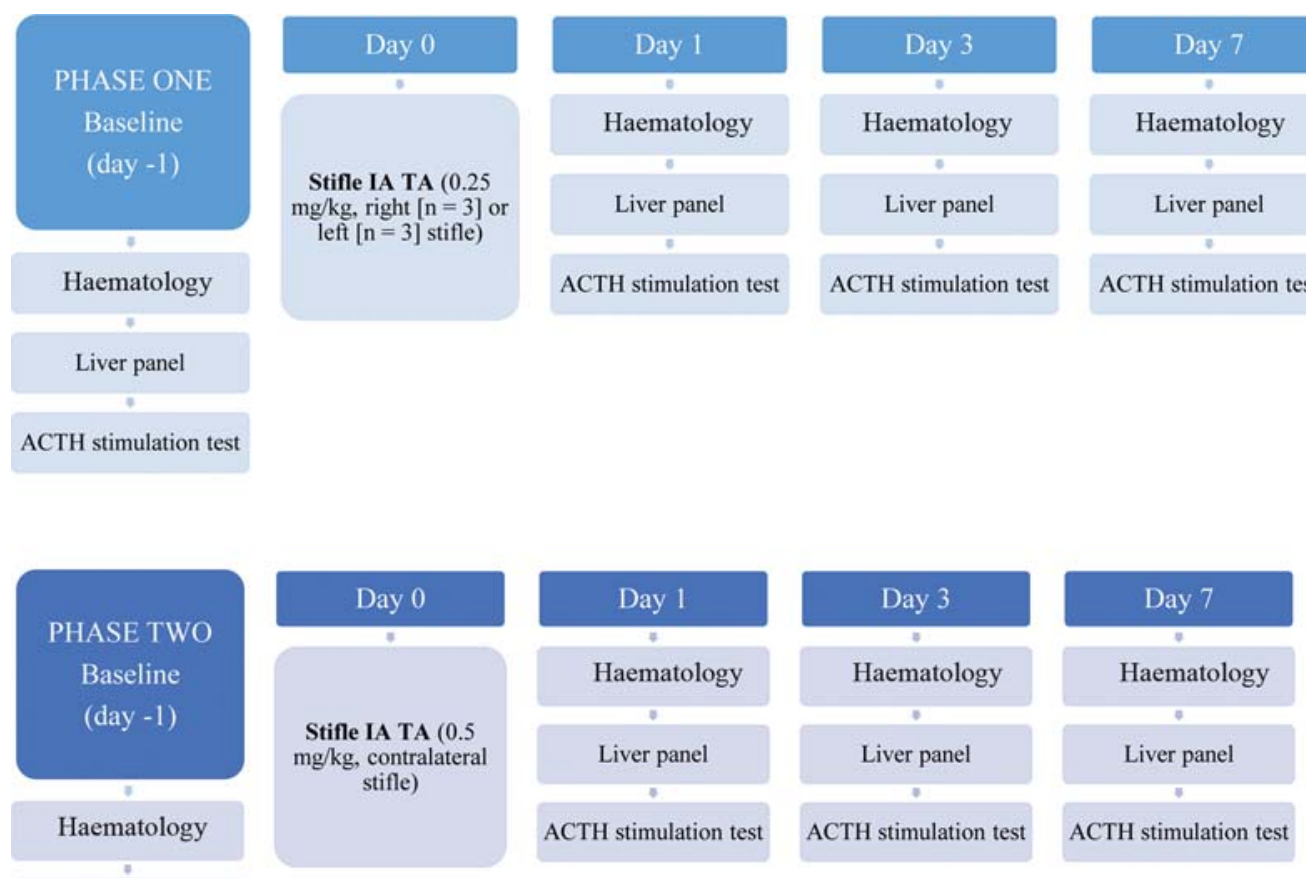

Liver panel

ACTH stimulation test

\section{Materials and Methods}

The study protocol was approved by the Institutional Animal Care and Use Committee of Cornell University (protocol 2018-0062). Six healthy, purpose-bred, naïve, adult (mean \pm standard deviation $[S D]$ age 6 years \pm 6 months), female intact beaglemixed mongrel dogs were enrolled. The mean dog weight was $11.8 \mathrm{~kg} \pm 1.3 \mathrm{~kg}$ with a range of 10 to $12.9 \mathrm{~kg}$.

The study consisted of two phases (- Fig. 1). In phase one, the right $(n=3)$ or left $(n=3)$ stifle was randomly selected for injection of $0.25 \mathrm{mg} / \mathrm{kg}$ of TA (Kenalog-10, Triamcinolone Acetonide Injectable Suspension USP $10 \mathrm{mg} / \mathrm{mL}$, Bristol-Myers Squibb, New York, New York, United States). In phase two, $0.5 \mathrm{mg} / \mathrm{kg}$ of TA was injected into the contralateral stifle. A 2week washout period separating the study phases commenced after serial laboratory work from phase one normalized. The time of IA TA administration was defined as day 0 for both phases. In both phases, one day before injection at baseline (day -1), each dog had a complete blood count (automated [haematology] Bayer Advia 2120i, Siemens Corporation, New York, New York, United States), liver panel (Cobas c501, Roche Diagnostics, Indianapolis, Indiana, United States) and ACTH stimulation test to obtain baseline data and rule out underlying disease that might preclude enrolment. A physical examination was performed on all dogs prior to enrolment. Haematology, liver panel, ACTH stimulation testing, a physical exam and general health history from kennel care attendants were gathered on days 1,3 and 7 and then weekly.

The liver panel consisted of liver-related biochemistry values including blood urea nitrogen, albumin, glucose, alanine aspartate transferase (ALT), aspartate amino transferase (AST), ALP,
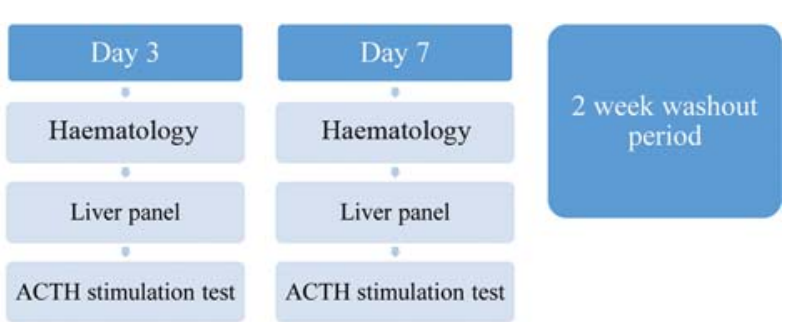

ACTH stimulation test

ACTH stimulation test

\section{Day 14}

ACTH stimulation test

Fig. 1 Schema of the study protocol laboratory work. ACTH, adrenocorticotropic hormone. 
gamma glutamyl transferase (GGT), total bilirubin, direct bilirubin, indirect bilirubin and cholesterol. Adrenocorticotropic hormone stimulation testing consisted of a pre-stimulation cortisol concentration followed by intravenous (IV) administration of synthetic ACTH (Cosyntropin for Injection $0.25 \mathrm{mg}$ per $2 \mathrm{~mL}$ suspension, Mylan, Canonsburg, Pennsylvania, United States) at a $5 \mu \mathrm{g} / \mathrm{kg}$ dog dosing. One hour after ACTH administration, serum was collected for post-stimulation cortisol concentration. All ACTH stimulation tests were conducted at approximately the same time in the afternoon for consistency with a validated canine assay (Immulite 1000 Cortisol Chemiluminescent Assay, Siemens Corporation, New York, New York, United States). ${ }^{24,25}$ The cross-reaction with triamcinolone for our cortisol assay was $0.022 \%$ according to the manufacturer. Throughout the study, venipuncture was conducted from a cephalic vein using a $21 \mathrm{~g}$ butterfly catheter connected to a vacutainer to fill two $5 \mathrm{~mL}$ coagulation and one $4 \mathrm{~mL}$ potassium ethylenediaminetetraaceticacid tube. After blood collection, ACTH was injected and flushed with $1 \mathrm{~mL}$ of sterile saline. About 1 to $2 \mathrm{~mL}$ of serum was collected again 1 hour after ACTH injection from the same vein with a 22-gauge needle and syringe and placed into a $5 \mathrm{~mL}$ coagulation tube. Cephalic veins were alternated as venipuncture sites each sampling day. Samples were submitted to the Cornell University Diagnostic Laboratory for processing and analysis.

The dogs were sedated IV after a 12-hour fasting with $5.0 \mu \mathrm{g} / \mathrm{kg}$ dexmedetomidine (Dexdomitor $0.5 \mathrm{mg} / \mathrm{mL}$, Zoetis, Kalamazoo, Michigan, United States) and $0.2 \mathrm{mg} / \mathrm{kg}$ methadone (Mylan $10 \mathrm{mg} / \mathrm{mL}$ Rockford, Illinois, United States) and monitored by a veterinary anaesthesiologist during IA injection. The selected stifle was clipped of hair and aseptically prepared in standard fashion. About $0.25 \mathrm{~mL}$ of 2\% lidocaine (LidoJect, Henry Schein Animal Health, Dublin, Ohio, United States) was infiltrated subcutaneously prior to needle placement. A $22 \mathrm{~g}, 1.5$ " needle was directed into the craniolateral stifle joint. Synovial fluid withdrawal without blood on aspiration confirmed placement before injecting $0.25 \mathrm{mg} / \mathrm{kg}$ of TA followed by $0.1 \mathrm{~mL}$ of saline flush. Atipamezole (Antisedan $5.0 \mathrm{mg} / \mathrm{mL}$, Zoetis, Kalamazoo, Michigan, United States) was administered IM for sedation reversal. Maropitant (Cerenia, Zoetis, Kalamazoo, Michigan, United States) was administered $2 \mathrm{mg} / \mathrm{kg}$ per os as needed for nausea.

\section{Statistical Analysis}

Initial power analysis was performed to assess number of dogs needed for this study as follows. Assuming that cortisol level is $12.5 \pm 2.91$ (mean $\pm \mathrm{SD}$ ) $\mu \mathrm{g} / \mathrm{dL} 1$ hour after $\mathrm{ACTH}$ injection, then a sample size of six dogs would detect a $25 \%$ reduction in post-stimulation cortisol level with an $\alpha$ of 0.05 and power of 0.8 .

Statistical analysis was performed with a commercially available software package (JMP Pro 13.0). The variables of interest were normally distributed, so a mixed-model analysis was applied. First, the differences between baselines prior to joint injection in both phases were assessed using a paired T-Test. Mixed model analysis was performed with the fixed effects of time, dose, the interaction of dose and time; as well as random effects of dog and dose nested within dog to account for repeated measurements for each dog. Residual diagnostics of all final models showed that residuals were normally distributed and fulfilled the assumption of homoscedasticity, and assumptions where therefore met. Pairwise comparisons between common time points in both phases were corrected for multiple comparisons with Tukey's post-hoc tests to examine the interaction of time, and to assess differences in change from baseline at any time point as they related to dose. Pre-ACTH cortisol concentrations were below the detection limit and significant different from baseline, but due to lack of numerical continuous data points at day 1 for dose 1 , only $-1,3$ and 7 were used for analysis. Similarly dose 2 day 1 and 3 data were below the lower limit of detection, so day -1 and 7 were analysed for dose, time and dose*time effects. Considering day 14 was collected for dose 2, a mixed model analysis of was performed without the fixed effect of dose to assess differences over time for both pre and post-ACTH cortisol concentrations. A p-value of less than 0.05 was defined as the significant.

\section{Results}

No abnormalities were noted from the history or during clinical examination of the dogs over the course of the study including adverse reactions to IA TA administration such as lameness, pain or swelling. Data were normally distributed, and baseline data did not significantly differ and was considered clinically normal. Due to a laboratory error, a haematology was unavailable for 1 dog on day 1 during phase two. Baseline haematology and liver panels were within the reference ranges for both phases (-Tables 1-2), except for a mild lymphopenia in 4/6 dogs in phase one. Mild decreases in haematocrit, haemoglobin and red blood cell values on day 1 were seen during phase two (-Table 1). A mild stress leukogram with neutrophilia, lymphopenia and eosinopenia was noted on day 1 of both phases ( - Table 1). All these values were significantly different from baseline except for the lymphopenia noted on day 1 of phase one, which was still outside the reference range. All values returned to baseline by day 3 . The only significant differences observed in serum biochemistry evaluation were ALP activity being significantly increased from baseline on day 3 during phase two (-Table 2). A significant increase in GGT from baseline without changes in serum ALT and AST was noted on day 3 in phase two (-Table 2 ).

Pre-stimulation cortisol level was also below the lower limit of detection $(1.80 \mu \mathrm{g} / \mathrm{dL})$ for four dogs $(0.75,0.97,1.76$ and 1.78 $\mathrm{ug} / \mathrm{dL})$ in the first phase and five dogs $(0.49,0.60,0.93,1.61$, $1.69 \mathrm{ug} / \mathrm{dL}$ ) in the second phase (-Table 3). Post-stimulation cortisol levels remained in the normal range at all time points for both phases. Following TA administration, cortisol values trended similarly over time in both phases. Mean pre-stimulation cortisol levels were significantly lower ( - Table 3 ) than baseline on day 1 , approaching 0 , and began to rise on day 3 and 7 in phases one and two, respectively, and neither phase differed from baseline by day 7 . There was a significant decrease in post-stimulation cortisol levels from baseline on days 1 and 3 of phase one and days 1 to 7 of phase two, returning to baseline by days 7 and 14 respectively (-Table 3 ). 
Table 1 Mean and standard deviation $(n=6)$ of complete blood counts in dogs receiving two different doses of intra-articular TA

\begin{tabular}{|c|c|c|c|c|c|c|c|c|c|}
\hline \multirow[t]{2}{*}{ Parameter } & \multirow{2}{*}{$\begin{array}{l}\text { Reference } \\
\text { range }\end{array}$} & \multirow{2}{*}{$\begin{array}{l}\text { TA dose } \\
(\mathrm{mg} / \mathrm{kg})\end{array}$} & \multicolumn{4}{|l|}{ Time } & \multicolumn{3}{|c|}{$p$-Value for fixed effects } \\
\hline & & & $\begin{array}{l}\text { Day-1 } \\
\text { Baseline }\end{array}$ & Day 1 & Day 3 & Day 7 & Time & Dose & Dose time \\
\hline \multirow[t]{2}{*}{ HCT } & \multirow[t]{2}{*}{$41-58 \%$} & $0.25 \mathrm{mg} / \mathrm{kg}$ & $50 \pm 3^{a}$ & $49 \pm 5^{a}$ & $51 \pm 4^{\mathrm{a}}$ & $52 \pm 4^{a}$ & \multirow[t]{2}{*}{$<0.01$} & \multirow[t]{2}{*}{0.98} & \multirow[t]{2}{*}{$<0.01$} \\
\hline & & $0.5 \mathrm{mg} / \mathrm{kg}$ & $52 \pm 4^{\mathrm{a}}$ & $45 \pm 4^{b}$ & $53 \pm 6^{a}$ & $51 \pm 4^{\mathrm{a}}$ & & & \\
\hline \multirow[t]{2}{*}{ Haemoglobin } & \multirow[t]{2}{*}{$14.1-20.1 \mathrm{~g} / \mathrm{dL}$} & $0.25 \mathrm{mg} / \mathrm{kg}$ & $17.2 \pm 1.2^{\mathrm{a}}$ & $17.3 \pm 1.7^{\mathrm{a}}$ & $17.3 \pm 1.4^{\mathrm{a}}$ & $17.8 \pm 1.5^{\mathrm{a}}$ & \multirow[t]{2}{*}{$<0.01$} & \multirow[t]{2}{*}{0.69} & \multirow[t]{2}{*}{$<0.01$} \\
\hline & & $0.5 \mathrm{mg} / \mathrm{kg}$ & $17.9 \pm 1.3^{\mathrm{a}}$ & $15.1 \pm 1.9^{b}$ & $18.0 \pm 1.6^{\mathrm{a}}$ & $17.3 \pm 1.6^{\mathrm{a}}$ & & & \\
\hline \multirow[t]{2}{*}{ RBC } & \multirow[t]{2}{*}{$5.7-8.5 \mathrm{mill} / \mu \mathrm{L}$} & $0.25 \mathrm{mg} / \mathrm{kg}$ & $7.1 \pm 0.6^{a}$ & $7.1 \pm 0.8^{\mathrm{a}}$ & $7.1 \pm 0.6^{\mathrm{a}}$ & $7.3 \pm 0.8^{a}$ & \multirow[t]{2}{*}{$<0.01$} & \multirow[t]{2}{*}{0.98} & \multirow[t]{2}{*}{0.002} \\
\hline & & $0.5 \mathrm{mg} / \mathrm{kg}$ & $7.4 \pm 0.4^{\mathrm{a}}$ & $6.4 \pm 0.8^{b}$ & $7.5 \pm 0.5^{\mathrm{a}}$ & $7.2 \pm 0.5^{a}$ & & & \\
\hline \multirow[t]{2}{*}{ WBC } & \multirow[t]{2}{*}{$5.7-14.2$ thou $/ \mu \mathrm{L}$} & $0.25 \mathrm{mg} / \mathrm{kg}$ & $8.1 \pm 1.6^{\mathrm{a}, \mathrm{b}}$ & $10.5 \pm 2.6^{b}$ & $6.6 \pm 1.5^{a}$ & $7.6 \pm 1.3^{a}$ & \multirow[t]{2}{*}{$<0.01$} & \multirow[t]{2}{*}{0.07} & \multirow[t]{2}{*}{0.28} \\
\hline & & $0.5 \mathrm{mg} / \mathrm{kg}$ & $8.4 \pm 1.4^{\mathrm{a}}$ & $13.0 \pm 2.1^{\mathrm{b}}$ & $8.0 \pm 1.2^{\mathrm{a}}$ & $8.3 \pm 1.5^{\mathrm{a}}$ & & & \\
\hline \multirow[t]{2}{*}{ Neutrophils } & \multirow[t]{2}{*}{$3.0-9.6$ thou $/ \mu \mathrm{L}$} & $0.25 \mathrm{mg} / \mathrm{kg}$ & $6.1 \pm 1.4^{\mathrm{a}}$ & $9.0 \pm 2.4^{b}$ & $4.1 \pm 0.7^{\mathrm{a}}$ & $5.7 \pm 1.2^{\mathrm{a}}$ & \multirow[t]{2}{*}{$<0.01$} & \multirow[t]{2}{*}{0.07} & \multirow[t]{2}{*}{0.07} \\
\hline & & $0.5 \mathrm{mg} / \mathrm{kg}$ & $5.7 \pm 1.2^{\mathrm{a}}$ & $11.3 \pm 1.7^{b}$ & $5.9 \pm 0.8^{\mathrm{a}}$ & $5.5 \pm 1.1^{\mathrm{a}}$ & & & \\
\hline \multirow[t]{2}{*}{ Lymphocytes } & \multirow[t]{2}{*}{$1.1-4.5$ thou $/ \mu \mathrm{L}$} & $0.25 \mathrm{mg} / \mathrm{kg}$ & $1.1 \pm 0.8^{\mathrm{a}}$ & $1.0 \pm 0.4^{\mathrm{a}}$ & $2.0 \pm 0.7^{b}$ & $1.9 \pm 0.5^{b}$ & \multirow[t]{2}{*}{$<0.01$} & \multirow[t]{2}{*}{0.49} & $<0.01$ \\
\hline & & $0.5 \mathrm{mg} / \mathrm{kg}$ & $1.9 \pm 0.4^{\mathrm{a}}$ & $1.2 \pm 0.5^{b}$ & $1.4 \pm 0.5^{\mathrm{a}}$ & $1.9 \pm 0.4^{\mathrm{a}}$ & & & \\
\hline Monocytes & $0.1-1.0$ thou $/ \mu \mathrm{L}$ & $0.25 \mathrm{mg} / \mathrm{kg}$ & $0.5 \pm 0.2^{\mathrm{a}}$ & $0.3 \pm 0.2^{\mathrm{a}}$ & $0.3 \pm 0.1^{\mathrm{a}}$ & $0.4 \pm 0.1^{\mathrm{a}}$ & 0.28 & $<0.01$ & $<0.01$ \\
\hline & & $0.5 \mathrm{mg} / \mathrm{kg}$ & $0.4 \pm 0.1^{a}$ & $0.5 \pm 0.1^{a}$ & $0.5 \pm 0.1^{a}$ & $0.6 \pm 0.1^{a}$ & & & \\
\hline Eosinophils & $0.1-2.1$ thou $/ \mu \mathrm{L}$ & $0.25 \mathrm{mg} / \mathrm{kg}$ & $0.3 \pm 0.1^{a}$ & $0^{\mathrm{b}}$ & $0.2 \pm 0.1^{\mathrm{a}, \mathrm{b}}$ & $0.3 \pm 0.1^{\mathrm{a}}$ & $<0.01$ & 0.02 & 0.19 \\
\hline & & $0.5 \mathrm{mg} / \mathrm{kg}$ & $0.3 \pm 0.1^{\mathrm{a}}$ & $0^{\mathrm{b}}$ & $0.1 \pm 0.1^{b, c}$ & $0.2 \pm 0.1^{\mathrm{a}, \mathrm{c}}$ & & & \\
\hline Platelets & $186-545$ thou/ $\mu \mathrm{L}$ & $0.25 \mathrm{mg} / \mathrm{kg}$ & $332 \pm 102^{\mathrm{a}}$ & $313 \pm 111^{\mathrm{a}}$ & $369 \pm 164^{a}$ & $343 \pm 109^{a}$ & 0.55 & 0.12 & 0.32 \\
\hline & & $0.5 \mathrm{mg} / \mathrm{kg}$ & $299 \pm 88^{a}$ & $325 \pm 90^{\mathrm{a}}$ & $301 \pm 91^{\mathrm{a}}$ & $271 \pm 143^{a}$ & & & \\
\hline
\end{tabular}

Abbreviations: $\mathrm{HCT}$, haematocrit; RBC, red blood cells; TA, triamcinolone acetonide; WBC, white blood cells.

Bold values are outside of the reference range.

a,b,c Significant $(p<0.05)$ differences between time points within each treatment (shared superscripts are not significantly different).

Table 2 Mean and standard deviation $(n=6)$ of serum biochemistry hepatic parameters in dogs receiving two different doses of IA TA

\begin{tabular}{|c|c|c|c|c|c|c|c|c|c|}
\hline \multirow[t]{2}{*}{ Parameter } & \multirow{2}{*}{$\begin{array}{l}\text { Reference } \\
\text { range }\end{array}$} & \multirow[t]{2}{*}{ Dose IA TA } & \multicolumn{4}{|c|}{ Time } & \multicolumn{3}{|c|}{$p$-Value for fixed effects } \\
\hline & & & $\begin{array}{l}\text { Day } 1 \\
\text { Baseline }\end{array}$ & Day 1 & Day 3 & Day 7 & Time & Dose & Dose ${ }^{*}$ time \\
\hline \multirow{2}{*}{$\begin{array}{l}\text { Urea } \\
\text { nitrogen }\end{array}$} & \multirow[t]{2}{*}{$9-26 \mathrm{mg} / \mathrm{dL}$} & $0.25 \mathrm{mg} / \mathrm{kg}$ & $19 \pm 5^{a}$ & $18 \pm 4^{a}$ & $18 \pm 5^{a}$ & $21 \pm 7^{a}$ & \multirow[t]{2}{*}{$<0.01$} & \multirow[t]{2}{*}{0.46} & \multirow[t]{2}{*}{0.18} \\
\hline & & $0.5 \mathrm{mg} / \mathrm{kg}$ & $22 \pm 4^{a}$ & $20 \pm 2^{a, b}$ & $15 \pm 3^{b}$ & $23 \pm 5^{a}$ & & & \\
\hline \multirow[t]{2}{*}{ Albumin } & \multirow[t]{2}{*}{$3.2-4.1 \mathrm{~g} / \mathrm{dL}$} & $0.25 \mathrm{mg} / \mathrm{kg}$ & $3.6 \pm 0.2^{\mathrm{a}}$ & $3.8 \pm 0.2^{\mathrm{a}}$ & $3.7 \pm 0.2^{a}$ & $3.6 \pm 0.1^{a}$ & \multirow[t]{2}{*}{$<0.01$} & \multirow[t]{2}{*}{0.55} & \multirow[t]{2}{*}{0.17} \\
\hline & & $0.5 \mathrm{mg} / \mathrm{kg}$ & $3.6 \pm 0.1^{\mathrm{a}}$ & $3.8 \pm 0.2^{b}$ & $3.7 \pm 0.2^{\mathrm{a}, \mathrm{b}}$ & $3.5 \pm 0.1^{\mathrm{a}}$ & & & \\
\hline \multirow[t]{2}{*}{ Glucose } & \multirow[t]{2}{*}{$68-104 \mathrm{mg} / \mathrm{dL}$} & $0.25 \mathrm{mg} / \mathrm{kg}$ & $80 \pm 5^{a}$ & $89 \pm 7^{a}$ & $85 \pm 10^{a}$ & $82 \pm 10^{a}$ & \multirow[t]{2}{*}{0.37} & \multirow[t]{2}{*}{0.76} & \multirow[t]{2}{*}{0.23} \\
\hline & & $0.5 \mathrm{mg} / \mathrm{kg}$ & $86 \pm 12^{a}$ & $82 \pm 14^{a}$ & $90 \pm 12^{a}$ & $83 \pm 7^{a}$ & & & \\
\hline \multirow[t]{2}{*}{ ALT } & \multirow[t]{2}{*}{$17-95 \mathrm{U} / \mathrm{L}$} & $0.25 \mathrm{mg} / \mathrm{kg}$ & $51 \pm 15^{a}$ & $48 \pm 20^{\mathrm{a}}$ & $59 \pm 22^{a}$ & $54 \pm 26^{a}$ & \multirow[t]{2}{*}{0.02} & \multirow[t]{2}{*}{0.13} & \multirow[t]{2}{*}{0.99} \\
\hline & & $0.5 \mathrm{mg} / \mathrm{kg}$ & $39 \pm 5^{a}$ & $38 \pm 6^{a}$ & $49 \pm 11^{\mathrm{a}}$ & $43 \pm 13^{a}$ & & & \\
\hline \multirow[t]{2}{*}{ AST } & \multirow[t]{2}{*}{$18-56 \mathrm{U} / \mathrm{L}$} & $0.25 \mathrm{mg} / \mathrm{kg}$ & $24 \pm 3^{a}$ & $24 \pm 8^{\mathrm{a}}$ & $21 \pm 2^{a}$ & $25 \pm 1^{a}$ & \multirow[t]{2}{*}{0.30} & \multirow[t]{2}{*}{0.35} & \multirow[t]{2}{*}{0.53} \\
\hline & & $0.5 \mathrm{mg} / \mathrm{kg}$ & $23 \pm 1^{a}$ & $20 \pm 4^{a}$ & $21 \pm 5^{a}$ & $22 \pm 2^{a}$ & & & \\
\hline \multirow[t]{2}{*}{ ALP } & \multirow[t]{2}{*}{$7-115 \mathrm{U} / \mathrm{L}$} & $0.25 \mathrm{mg} / \mathrm{kg}$ & $47 \pm 33^{\mathrm{a}, \mathrm{b}}$ & $56 \pm 37^{a}$ & $56 \pm 29^{a}$ & $41 \pm 21^{b}$ & \multirow[t]{2}{*}{$<0.01$} & \multirow[t]{2}{*}{0.84} & \multirow[t]{2}{*}{0.09} \\
\hline & & $0.5 \mathrm{mg} / \mathrm{kg}$ & $38 \pm 14^{\mathrm{a}}$ & $51 \pm 19^{\mathrm{a}, \mathrm{b}}$ & $63 \pm 24^{b}$ & $41 \pm 16^{\mathrm{a}}$ & & & \\
\hline GGT & $0-8 \mathrm{U} / \mathrm{L}$ & $0.25 \mathrm{mg} / \mathrm{kg}$ & $5 \pm 1^{\mathrm{a}}$ & $5 \pm 2^{a}$ & $6 \pm 2^{a}$ & $5 \pm 2^{a}$ & 0.03 & 0.23 & 0.13 \\
\hline & & $0.5 \mathrm{mg} / \mathrm{kg}$ & $4 \pm 1^{\mathrm{a}}$ & $4 \pm 1^{\mathrm{a}}$ & $9 \pm 7^{b}$ & $5 \pm 1^{\mathrm{a}, \mathrm{b}}$ & & & \\
\hline Cholesterol & $136-392 \mathrm{mg} / \mathrm{dL}$ & $0.25 \mathrm{mg} / \mathrm{kg}$ & $210 \pm 58^{a}$ & $201 \pm 58^{a}$ & $215 \pm 58^{a}$ & $212 \pm 20^{a}$ & $<0.01$ & 0.15 & 0.13 \\
\hline & & $0.5 \mathrm{mg} / \mathrm{kg}$ & $235 \pm 43^{\mathrm{a}, \mathrm{b}}$ & $213 \pm 40^{\mathrm{a}}$ & $248 \pm 47^{b}$ & $223 \pm 34^{a}$ & & & \\
\hline
\end{tabular}

Abbreviations: ALP, alkaline phosphatase; ALT, alanine aspartate transferase; AST, aspartate aminotransferase; GGT, gamma glutamyl transferase; IA, intra-articular; TA, triamcinolone acetonide.

Bold values are outside of the reference range.

a,b,c,d Significant $(p<0.05)$ differences from each time point within each treatment (shared superscripts are not significantly different). 


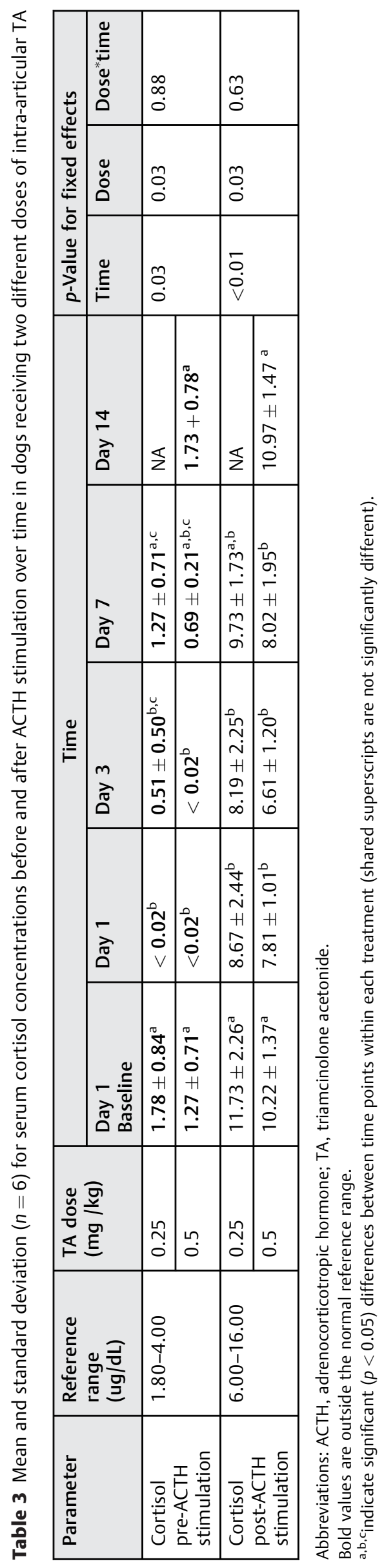

\section{Discussion}

Our findings suggest mild transient systemic changes from IA TA in healthy adult mongrel dogs without any clear adverse effects. We noted suppression of cortisol levels compared with baseline resolving by day 3 or 7 for phase one and two respectively. Minimal elevations in ALP within reference range occurred on day 3 of phase two and some mild clinical pathological changes associated with HAC also occurred and resolved between days 3 to 7 for both phases. At no point during the study were clinical findings consistent with HAC and dogs remained healthy.

The first objective of this study was to determine if IA injection of TA suppresses the HPA. Endogenous glucocorticoids are regulated by the HPA and are produced in the adrenal cortex. Both endogenous and exogenous glucocorticoids exert negative regulatory feedback on the HPA, suppressing ATCH release, and, therefore, cortisol production. In people, the extent of exogenous glucocorticoid adrenal suppression depends on the type, frequency, dose and patient. ${ }^{26-28}$ Iatrogenic HAC can also result from administration of corticosteroids, although this is not as commonly reported as adrenocortical suppression in the context of IA dosing. ${ }^{29,30}$

Signalment (age and sex) as well as diurnal fluctuations were controlled for by population and sampling time when assessing HPA, ${ }^{31,32}$ leaving only the fixed effects of dose, time and dose ${ }^{*}$ time. Baseline (day -1) pre-stimulation cortisol level was below the reference range for four dogs in phase one and five dogs in phase two. These dogs had normal post-stimulation cortisol levels and exhibited no evidence of adrenal damage, critical illness or inflammation upon screening that explained their pre-stimulation cortisol levels. ${ }^{24}$ Interestingly, our basal cortisol results could be reflective of age as they were similar to a cohort of 3 to 5 year-old dogs in a study assessing the influence of aging on adrenal responsiveness in healthy beagles. ${ }^{31}$ For all these reasons, these dogs were considered clinically normal and not excluded for study purposes.

After IA TA injection, pre-stimulation cortisol levels decreased, but returned to baseline by day 7 in both phases. Furthermore, post-stimulation cortisol levels were significantly decreased, but returned to baseline by day 7 and 14 in phase one and two respectively. Despite a $p$-value of 0.03 , demonstrating that TA dose difference impacted overall cortisol response, no difference was found using conservative Tukey's post hoc testing when assessing cortisol levels between phases at each time point ( - Table 3 ). Therefore, both doses impacted cortisol production through a negative feedback mechanism similarly over time, aligning with our primary hypothesis. The post-ACTH stimulation results continued to reflect a degree of negative feedback from TA, suppressing the HPA, compared with baseline although remaining within in normal range. Comparatively, a similar pattern has been described in previous studies examining suppression using topical glucocorticoids. ${ }^{19}$ Therefore, the degree of suppression for both doses is transient and may be considered mild, without suspicion of adrenal atrophy or damage, given patient health and the normal post-ACTH stimulation results. In a recent study on beagle dogs, IA TA injections were compared with an extended release 
IA TA. ${ }^{23}$ Plasma concentrations of a single $18.75 \mathrm{mg}$ IA TA dose were measured over time and demonstrated a peak concentration rapidly within hours that decreased dramatically over 3 days and was undetectable by 2 weeks. Although the IA TA dosage used was much larger than ours, the pattern of plasma absorption and clearance helps explain the duration of suppression we noted during our ACTH stimulation testing.

The second objective was to determine if, to what extent, and for how long IA injection of TA increases serum ALP activity. Serum ALP remains a practical and sensitive screening tool for HAC or exogenous corticosteroid use due to the induction of ALP isoenzyme (C-ALP). ${ }^{33}$ On the other hand, ALP as measured in our study is not specific for a single isoenzyme (such as C-ALP) but instead captures and groups multiple isoenzymes together. Considering the age and health of the dogs in this study, ALP elevations were presumed to be corticosteroid induced. mildly increased within the normal reference range on day 3 during phase two, and therefore most likely reflected induction from TA. A similar insignificant trend was noted in phase one. These findings partially support our second hypothesis for phase two. Surprisingly, ALP never increased above the upper end of the reference range interval. However, the observation of increased ALP activity first occurring on day 3 in phase two only may be attributed to a delay in enzyme activity induction from triamcinolone dosing; and that, in general, the type, dose and frequency of administration of a corticosteroid can affect the patterns of ALP enzyme induction over time. $^{34}$

The third objective was to determine if IA injection of TA causes other clinicopathological abnormalities consistent with iatrogenic HAC. The stress leukogram noted on day 1 in both phases is a common finding after corticosteroid injection and was not surprising. The absence of erythrocytosis and instead, a mild but significant decrease in haematocrit, haemoglobin and red blood cells on day 1 in phase two was unexpected; the cause and clinical relevance are uncertain. Least squares mean GGT on day 3 in phase two was higher than normal limits at $9 \mathrm{U} / \mathrm{L}$ due to a GGT of $20 \mathrm{U} / \mathrm{L}$ in one dog. The value may be spurious given the absence of clinical illness and normal serum ALT and AST findings.

Our study had several limitations beyond small sample size. We selected doses of $0.25 \mathrm{mg} / \mathrm{kg}$ and $0.5 \mathrm{mg} / \mathrm{kg}$ TA based on prior human and veterinary studies. ${ }^{8,10,20-22}$ Despite the chondroprotective effects of TH for canine OA, IATA is a more logical choice to investigate given its greater availability in veterinary medicine and published data regarding its pharmacokinetics and local stifle joint effects in the dog. ${ }^{23}$ As a safety strategy, we assessed the effects of the $0.25 \mathrm{mg} / \mathrm{kg}$ dose first before proceeding with the higher $0.5 \mathrm{mg} / \mathrm{kg}$ injection, preventing dose-randomization. However, siterandomization between right and left stifle was performed. Another constraint of the study was the absence of a control group (a sham and/or saline injection group). For ethical and logistical reasons, we assessed baseline values for each phase and applied a mixed model of covariance analysis to help account for the lack of control and complete randomization. Lastly, our safety trial only accounted for healthy dogs; however, IA TA clinical application is for OA treatment. Because inflammation inherent to $O A$ increases synovial permeability, $^{35}$ it may increase systemic effects of IA glucocorticoids. $^{36,37}$

In summary, mild transient suppression of endogenous cortisol production was noted for up to 3 days following IATA injection in healthy dogs regardless of dose; however, adrenal response to ACTH stimulation testing was normal in all phases. All haematology and chemistry value changes were minimal and transient. Furthermore, no dogs experienced clinical signs associated with HAC, joint injection or other diseases attributable to exogenous IA corticosteroid supplementation. In conclusion, systemic adverse effects following local IA administration of TA in healthy canine stifle joints are unlikely at both 0.25 and $0.5 \mathrm{mg} / \mathrm{kg}$. We hope this trial encourages further research into the safety and clinical efficacy of IA corticosteroid therapy.

Note

The study protocol was approved by the Institutional Animal Care and Use Committee of Cornell University (protocol No. 2018-0062).

\section{Funding}

This study was funded by the Cornell University 2018 Resident Research Grants Program.

\section{Conflict of Interest}

None declared.

\section{References}

1 McAlindon TE, Bannuru RR, Sullivan MC, et al. OARSI guidelines for the non-surgical management of knee osteoarthritis. Osteoarthritis Cartilage 2014;22(03):363-388

2 Aragon CL, Hofmeister EH, Budsberg SC. Systematic review of clinical trials of treatments for osteoarthritis in dogs. J Am Vet Med Assoc 2007;230(04):514-521

3 Johnston SA, McLaughlin RM, Budsberg SC. Nonsurgical management of osteoarthritis in dogs. Vet Clin North Am Small Anim Pract 2008;38(06):1449-1470, viii

4 Gagnon A, Brown D, Moreau M, Lussier B, Otis C, Troncy E. Therapeutic response analysis in dogs with naturally occurring osteoarthritis. Vet Anaesth Analg 2017;44(06):1373-1381

5 Godwin M, Dawes M. Intra-articular steroid injections for painful knees. Systematic review with meta-analysis. Can Fam Physician 2004;50(FEB):241-248

6 Bellamy N, Campbell J, Robinson V, Gee T, Bourne R, Wells G. Intraarticular corticosteroid for treatment of osteoarthritis of the knee. Cochrane Database Syst Rev 2005;(02):CD005328www. cochranelibrary.com. Doi: 10.1002/14651858.CD005328

7 Scherer J, Rainsford KD, Kean CA, Kean WF. Pharmacology of intraarticular triamcinolone. Inflammopharmacology 2014;22(04): 201-217

8 McAlindon TE, LaValley MP, Harvey WF, et al. Effect of intraarticular triamcinolone vs saline on knee cartilage volume and pain in patients with knee osteoarthritis a randomized clinical trial. JAMA 2017;317(19):1967-1975

9 Lomonte ABV, de Morais MGV, de Carvalho LO, Zerbini Cde F. Efficacy of triamcinolone hexacetonide versus methylprednisolone acetate intraarticular injections in knee osteoarthritis: a randomized, double-blinded, 24-week study. J Rheumatol 2015; 42(09):1677-1684 
10 Popma JW, Snel FW, Haagsma CJ, et al. Comparison of 2 dosages of intraarticular triamcinolone for the treatment of knee arthritis: results of a 12-week randomized controlled clinical trial. J Rheumatol 2015;42(10):1865-1868

11 Byron CR, Benson BM, Stewart AA, Pondenis HC. Effects of methylprednisolone acetate and glucosamine on proteoglycan production by equine chondrocytes in vitro. Am J Vet Res 2008;69 (09):1123-1128

12 Carter BG, Bertone AL, Weisbrode SE, Bailey MQ, Andrews JM, Palmer JL. Influence of methylprednisolone acetate on osteochondral healing in exercised tarsocrural joints of horses. Am J Vet Res 1996;57(06):914-922http://www.ncbi.nlm.nih.gov/pubmed/ 8725823

13 Chunekamrai S, Krook LP, Lust G, Maylin GA. Changes in articular cartilage after intra-articular injections of methylprednisolone acetate in horses. Am J Vet Res 1989;50(10):1733-1741http:// www.ncbi.nlm.nih.gov/pubmed/2802304

14 Frisbie DD, Kawcak CE, Trotter GW, Powers BE, Walton RM, McIlwraith CW. Effects of triamcinolone acetonide on an in vivo equine osteochondral fragment exercise model. Equine Vet J 1997;29(05):349-359

15 Kay AT, Bolt DM, Ishihara A, Rajala-Schultz PJ, Bertone AL. Antiinflammatory and analgesic effects of intra-articular injection of triamcinolone acetonide, mepivacaine hydrochloride, or both on lipopolysaccharide-induced lameness in horses. Am J Vet Res 2008;69(12):1646-1654

16 McIlwraith CW, Lattermann C, Lattermann C. Intra-articular corticosteroids for knee pain-what have we learned from the equine athlete and current best practice. J Knee Surg 2019;32(01): 9-25

17 Kemppainen RJ, Lorenz MD, Thompson FN. Adrenocortical suppression in the dog given a single intramuscular dose of prednisone or triamcinolone acetonide. Am J Vet Res 1982;43(02): 204-206http://www.ncbi.nlm.nih.gov/pubmed/6283956

18 Moriello KA, Fehrer-Sawyer SL, Meyer DJ, Feder B. Adrenocortical suppression associated with topical otic administration of glucocorticoids in dogs. J Am Vet Med Assoc 1988;193(03):329-331http://www.ncbi.nlm.nih.gov/pubmed/2846483

19 Zenoble RD, Kemppainen RJ. Adrenocortical suppression by topically applied corticosteroids in healthy dogs. J Am Vet Med Assoc 1987;191(06):685-688

20 Pelletier JP, Martel-Pelletier J. In vivo protective effects of prophylactic treatment with tiaprofenic acid or intraarticular corticosteroids on osteoarthritic lesions in the experimental dog model. J Rheumatol Suppl 1991;27(Suppl 27):127-130

21 Pelletier JP, DiBattista JA, Raynauld JP, Wilhelm S, Martel-Pelletier $\mathrm{J}$. The in vivo effects of intraarticular corticosteroid injections on cartilage lesions, stromelysin, interleukin-1, and oncogene protein synthesis in experimental osteoarthritis. Lab Invest 1995;72 (05):578-586

22 Pelletier JP, Martel-Pelletier J. Protective effects of corticosteroids on cartilage lesions and osteophyte formation in the Pond-Nuki dog model of osteoarthritis. Arthritis Rheum 1989;32(02): 181-193

23 Bodick N, Williamson T, Strand V, et al. Local effects following single and repeat intra-articular injections of triamcinolone acetonide extended-release: results from three nonclinical toxicity studies in dogs. Rheumatol Ther 2018;5(02):475-498

24 Bovens C, Tennant K, Reeve J, Murphy KF. Basal serum cortisol concentration as a screening test for hypoadrenocorticism in dogs. J Vet Intern Med 2014;28(05):1541-1545

25 Russell NJ, Foster S, Clark P, Robertson ID, Lewis D, Irwin PJ Comparison of radioimmunoassay and chemiluminescent assay methods to estimate canine blood cortisol concentrations. Aust Vet J 2007;85(12):487-494

26 Reid DM, Patel S, Reid IW, Eastmond CJ, Rennie JA. Hypothalamicpituitary-adrenal (HPA) axis function in patients receiving long-term intra-articular corticosteroids. Clin Rheumatol 1983;2(02):159-161

27 Huppertz HI, Pfüller H. Transient suppression of endogenous cortisol production after intraarticular steroid therapy for chronic arthritis in children. J Rheumatol 1997;24(09):1833-1837

28 Duclos M, Guinot M, Colsy M, et al. High risk of adrenal insufficiency after a single articular steroid injection in athletes. Med Sci Sports Exerc 2007;39(07):1036-1043

29 Hameed R, Zacharin MR. Cushing syndrome, adrenal suppression and local corticosteroid use. J Paediatr Child Health 2006;42(06): 392-394

30 O'Sullivan MM, Rumfeld WR, Jones MK, Williams BD. Cushing's syndrome with suppression of the hypothalamic-pituitary-adrenal axis after intra-articular steroid injections. Ann Rheum Dis 1985;44(08):561-563

31 Goy-Thollot I, Decosne-Junot C, Bonnet J-M. Influence of aging on adrenal responsiveness in a population of eleven healthy beagles. Res Vet Sci 2007;82(02):195-201

32 Pessina P, Fernández-Foren A, Cueto E, Delucchi L, Castillo V, Meikle A. Cortisol secretion after adrenocorticotrophin (ACTH) and dexamethasone tests in healthy female and male dogs. Acta Vet Scand 2009;51(01):33. Doi: 10.1186/1751-0147-51-33

33 Kidney BA, Jackson ML. Diagnostic value of alkaline phosphatase isoenzyme separation by affinity electrophoresis in the dog. Can J Vet Res 1988;52(01):106-110

34 Fernandez NJ, Kidney BA. Alkaline phosphatase: beyond the liver. Vet Clin Pathol 2007;36(03):223-233

35 Evans $\mathrm{CH}$, Kraus VB, Setton LA. Progress in intra-articular therapy. Nat Rev Rheumatol 2014;10(01):11-22

36 Rudnik-Jansen I, Colen S, Berard J, et al. Prolonged inhibition of inflammation in osteoarthritis by triamcinolone acetonide released from a polyester amide microsphere platform. J Control Release 2017;253:64-72

37 Bodick N, Lufkin J, Willwerth C, et al. An intra-articular, extendedrelease formulation of triamcinolone acetonide prolongs and amplifies analgesic effect in patients with osteoarthritis of the knee: a randomized clinical trial. J Bone Joint Surg Am 2015;97 (11):877-888 